\title{
Editorial
}

\section{Mudanças e novos desafios}

Changes and new challenges

A Coordenação do Programa de Pós-Graduação (Mestrado) em Comunicação da UEL passou a administrar exclusivamente a revista Discursos Fotográficos e promoveu algumas mudanças que já começaram a ser executadas a partir desta edição.

A primeira mudança está na coordenação de edição, que passa a ser realizada de maneira rotativa. A cada edição, dois professores do programa terão a oportunidade e o desafio de assumirem a tarefa de editor, exigindo responsabilidade e comprometimento para dar continuidade ao trabalho já realizado até agora, que colocou nossa revista num patamar de excelência.

A segunda mudança diz respeito à estrutura da revista. A partir da edição do segundo semestre de 2014, a Discursos Fotográficos contará com dossiês temáticos. O primeiro tema de dossiê versará sobre "Comunicação e Política", tema mais do que pertinente se considerarmos que o ano de 2014 é um ano eleitoral e esse processo certamente será retratado e representado com fartura por meio de imagens.

A terceira mudança está relacionada diretamente ao conteúdo desta edição. Apesar de insistirmos em afirmar que - apesar do nome da revista sugerir uma exclusividade para a área da fotografia - a Discursos Fotográficos está voltada para temáticas relacionadas à comunicação visual em geral, as contribuições que temos recebido são 
predominantemente voltadas a estudos e análises de fotografia. Ao contrário de edições anteriores, pudemos verificar que os pesquisadores em outras áreas da comunicação visual perceberam que seus trabalhos são bem vindos em nossa revista e, com isso, passaram a submeter seus artigos para a Discursos Fotográficos, o que nos possibilitou publicar dois artigos trazendo o cinema como ambiente de análise.

A fotografia documental de Cláudia Andujar, as fotografias de guerra como ícones dos respectivos eventos históricos e o debate em torno do respeito à dignidade humana e sua necessária relação com o debate da ética no fotojornalismo também são temas abordados nesta edição.

Um exercício de leitura semiótica de fotografias é proposto para analisar as manifestações pela manutenção de uma instituição pública de ensino superior. Compreender a questão da "aura" e do "olhar pósmoderno" também são desafios propostos por nossos autores. Enfim, para conhecer com detalhes cada um dos estudos e análises propostos, basta folhear as páginas desta edição e participar ativamente dos debates suscitados por nossa publicação.

Boa leitura e estejam todos convidados a participar com suas discussões e análises em nossas próximas edições, inclusive, apresentando propostas para os dossiês temáticos.

Os editores 